\title{
Heat exhaustion in a deep underground metalliferous mine
}

\author{
A Michael Donoghue, Murray J Sinclair, Graham P Bates
}

\begin{abstract}
Objectives-To examine the incidence, clinical state, personal risk factors, haematology, and biochemistry of heat exhaustion occurring at a deep underground metalliferous mine. To describe the underground thermal conditions associated with the occurrence of heat exhaustion.
\end{abstract}

Methods-A 1 year prospective case series of acute heat exhaustion was undertaken. A history was obtained with a structured questionnaire. Pulse rate, blood pressure, tympanic temperature, and specific gravity of urine were measured before treatment. Venous blood was analysed for haematological and biochemical variables, during the acute presentation and after recovery. Body mass index (BMI) and maximum $\mathrm{O}_{2}$ consumption ( $\left.\dot{\mathrm{V}}_{2} \mathbf{m a x}\right)$ were measured after recovery. Psychrometric wet bulb temperature, dry bulb temperature, and air velocity were measured at the underground sites where heat exhaustion had occurred. Air cooling power and psychrometric wet bulb globe temperature were derived from these data.

Results-106 Cases were studied. The incidence of heat exhaustion during the year was 43.0 cases / million man-hours. In February it was 147 cases / million man-hours. The incidence rate ratio for mines operating below $1200 \mathrm{~m}$ compared with those operating above $1200 \mathrm{~m}$ was 3.17. Mean estimated fluid intake was 0.64 1/h (SD 0.29, range $0.08-1.50$ ). The following data were increased in acute presentation compared with recovery ( $p$ value, $\%$ of acute cases above the normal clinical range): neutrophils $(\mathrm{p}<0.001,36 \%)$, anion gap $(\mathrm{p}<0.001$, $63 \%)$, urea $(\mathrm{p}<0.001,21 \%)$, creatinine $(\mathrm{p}<0.001,30 \%)$, glucose $(\mathrm{p}<0.001,15 \%)$, serum osmolality $(p=0.030,71 \%)$, creatine kinase $(\mathrm{p}=0.002,45 \%)$, aspartate transaminase $(p<0.001,14 \%)$, lactate dehydrogenase $(\mathrm{p}<0.001,9.5 \%)$, and ferritin $(\mathrm{p}<0.001$, $26 \%)$. The following data were depressed in acute presentation compared with recovery ( $p$ value, \% of acute cases below the normal clinical range): eosinophils $(p=0.003,38 \%)$ and bicarbonate $(p=0.011$, $32 \%)$. Urea and creatinine were significantly increased in miners with heat cramps compared with miners without this symptom $(p<0.001)$, but there was no significant difference in sodium concentration $(p=0.384)$. Mean psychrometric wet bulb temperature was $29.0^{\circ} \mathrm{C}$ (SD 2.2, range $21.0-34.0$ ). Mean dry bulb tempera- ture was $37.4^{\circ} \mathrm{C}$ (SD 2.4, range 31.0-43.0). Mean air velocity was $0.54 \mathrm{~m} / \mathrm{s}$ (SD 0.57 , range 0.00-4.00). Mean air cooling power was $148 \mathrm{~W} / \mathrm{m}^{2}$ (SD 49, range 33-290) Mean psychrometric wet bulb globe temperature was $31.5^{\circ} \mathrm{C}$ (SD 2.0, range 25.2-35.3). Few cases $(<5 \%)$ occurred at psychrometric wet bulb temperature $<25.0^{\circ} \mathrm{C}$, dry bulb temperature $<33.8^{\circ} \mathrm{C}$, air velocity $>1.56$ $\mathrm{m} / \mathrm{s}$, air cooling power $>248 \mathrm{~W} / \mathrm{m}^{2}$, or psychrometric wet bulb globe temperature $<28.5^{\circ} \mathrm{C}$.

Conclusion-Heat exhaustion in underground miners is associated with dehydration, neutrophil leukocytosis, eosinopenia, metabolic acidosis, increased glucose and ferritin, and a mild rise in creatine kinase, aspartate transaminase, and lactate dehydrogenase. Heat cramps are associated with dehydration but not hyponatraemia. The incidence of heat exhaustion increases during summer and at depth. An increased fluid intake is required. Heat exhaustion would be unlikely to occur if ventilation and refrigeration achieved air cooling power $>250 \mathrm{~W} / \mathrm{m}^{2}$ at all underground work sites.

(Occup Environ Med 2000;57:165-174)

Keywords: heat; mining; ventilation

Deep underground mines are hot and humid for several reasons ${ }^{12}$ : the surface air temperature and humidity may be high, especially in tropical regions. Virgin rock temperature increases with depth (geothermal gradient). Air temperature also increases with depth due to increasing air pressure (autocompression). Groundwater and mine water transfer heat to the air by evaporation and increase the humidity. Most of the energy consumed by mining machinery and equipment, be it electrical, compressed air, or diesel, is liberated as heat. Less important sources of heat underground include human metabolism, oxidation processes, explosive blasting, rock movement, and pipelines.

Heat stroke in underground miners has often been found in South African mines. ${ }^{3-7}$ Heat stroke is often fatal and is distinguished from the less severe condition of heat exhaustion by tissue damage, caused by more severe or prolonged increases in body temperature. ${ }^{89}$ This is best assessed by serum assays of tissue enzymes - such as aspartate transaminase, alanine transaminase, lactate dehydrogenase, and creatine kinase. ${ }^{58}$ Clinically heat stroke is distinguished from heat exhaustion by disturbances of the central nervous system, usually 
prolonged unconsciousness, often preceded by confusion, ataxia, or convulsions. ${ }^{6-11}$ The core temperature is almost always over $40^{\circ} \mathrm{C}$ at onset whereas this is very rarely the case in heat exhaustion. $^{9}{ }^{10}$ The core temperature may fall before presentation, however, so it is not vital to the diagnosis of heat stroke. ${ }^{911}$ Heat exhaustion is caused by the inability of the circulatory system to simultaneously supply sufficient blood flow to the skin to achieve adequate heat loss and to supply the vital organs and exercising skeletal muscle. ${ }^{8}$ It is usually due to hypovolaemia resulting from varying degrees of water and salt loss. ${ }^{8}$ People with heat exhaustion may develop fatigue, headache, dizziness, anorexia, nausea, vomiting, shortness of breath, or syncope. ${ }^{8}$ Confusion, ataxia, prolonged unconsciousness, or convulsions are strongly suggestive of heat stroke.

Heat cramps are painful involuntary contractions of skeletal muscle associated with work in hot conditions. The limbs are usually involved and the spasms typically last a few minutes during which the affected part is incapacitated. The underlying mechanism is unknown, and there is conflict as to the role of dehydration and salt depletion. ${ }^{8}$

Our study was undertaken at a deep $(1800 \mathrm{~m}$ maximum depth) underground metalliferous mine in tropical arid Australia. In 1967 Wyndham et al developed thermal exposure limits for underground mining designed primarily to prevent heatstroke. ${ }^{12}$ These limits have been used at this mine and although no case of heatstroke has been recorded, heat exhaustion and heat cramps remain common. We have received several inquiries about heat exhaustion from underground mines elsewhere in Australia, however, no data on the incidence or severity of this problem exist. Heat exhaustion in underground miners has been the subject of only one paper, from South Africa, which was restricted to an analysis of serum electrolytes. ${ }^{13}$ Our study aimed to elucidate the incidence of heat exhaustion and describe the clinical state, personal risk factors, haematology, and biochemistry. It also aimed to describe the underground thermal conditions associated with the occurrence of heat exhaustion.

\section{Method}

A 1 year prospective case series of acute heat exhaustion was undertaken from 1 October 1997 to 31 September 1998. All underground miners requesting treatment from the mine's medical centre for symptoms of heat exhaustion were considered for inclusion in the series. The mine's medical centre is open 24 hours/ day, 7 days/week and undertakes the emergency retrieval and treatment of all workers in the event of illness or injury. Usually cases of heat exhaustion are reported by the emergency telephone line and the miners are retrieved from underground by four wheel drive ambulance and are taken to the medical centre. Entry to the study required a history of considerable heat exposure and the presence of one or more symptoms of heat exhaustion starting after beginning work (headache, dizziness, fatigue, nausea, vomiting, transient loss of con- sciousness) and the reasonable clinical exclusion of alternative diagnoses. The only exception to the symptom criteria, were two subjects presenting during the study period with heat cramps alone. All but two study subjects were attended to upon presentation by AMD or MJS. A locum medical officer saw one of these two and an occupational health nurse saw the other. Both people used the structured questionnaire and protocol.

All people with occupational illness or injury presenting to the medical centre are entered into the mine's computer injury database by occupational health nurses. It was therefore possible to ascertain how many cases of heat exhaustion were missed during the study period.

On entry to the study, a history was taken with a structured questionnaire. This covered details of the work location, job done, start time, estimated fluid intake, whether alcohol had been consumed in the last 24 hours, current illnesses, current medication, whether it was the first shift after rostered days off, whether the subject had left the tropics in the past 2 weeks, and symptoms (cramps, headache, dizziness, fatigue, nausea, vomiting, diarrhea, loss of consciousness, confusion, convulsions). Fluid intake was estimated according to the history of fluid consumption from standard capacity water bottles (4 1) and any other non-standard vessels.

The pulse, recumbent blood pressure, and tympanic temperature were recorded.

Venous blood was tested for the following haematological and biochemical variables: haemoglobin, red cell count, packed cell volume, mean cell volume, mean cell haemoglobin, white cell count, neutrophils, lymphocytes, monocytes, eosinophils, basophils, sodium, potassium, chloride, bicarbonate, anion gap, glucose, urea, creatinine, osmolality, alanine transaminase, creatine kinase, aspartate transaminase, lactate dehydrogenase, activated partial thromboplastin time, prothrombin time, lactate, ascorbate, iron, total iron binding capacity, transferrin saturation, and ferritin. The blood analyses were undertaken by a medical laboratory registered by the Royal College of Pathologists of Australasia.

A urine sample was tested for specific gravity with an Atago refractometer.

Treatment consisted of either oral fluids or intravenous normal saline, given in an air conditioned treatment room of the medical centre.

During the acute presentation, AMD or MJS contacted the ventilation manager or his deputy, to arrange measurements at the underground site where the miner had been working. Psychrometric wet bulb temperature, and dry bulb temperature were measured with a sling psychrometer with mercury thermometers. Air velocity was measured by vane anemometer.

Air cooling power and psychrometric wet bulb globe temperatures were calculated from these data.

Air cooling power is a calculated rate of heat transfer from a person to the environment in which he or she is working. Its calculation has been refined over many years. ${ }^{14-17}$ In its most 
simple form it is represented by the following formula:

$$
\text { air cooling power }=\mathrm{R}+\mathrm{C}+\mathrm{E}\left(\mathrm{W} / \mathrm{m}^{2}\right)
$$

$\mathrm{R}=$ radiant heat transfer, $\mathrm{C}=$ convective heat transfer, $\mathrm{E}=$ evaporative heat transfer.

The effect of respiratory heat loss is not considered in the air cooling power calculation, as it has been shown to be negligible during typical underground thermal conditions. ${ }^{17}$ Conductive heat transfer is also not included as bodily contact with solid surroundings during modern mining is limited. ${ }^{1}$

Air cooling power (Brake et al personal communication) was calculated with the measured values of psychrometric wet bulb temperature, dry bulb temperature, and air velocity, making the following assumptions:

(1) The radiant heat calculations used dry bulb temperature instead of globe temperature. In the underground environment the two temperatures seldom differ by more than one degree. ${ }^{18}$ Radiant heat is only of significance when working near freshly fired faces or near diesel haulage vehicles.

(2) The barometric pressure was $110 \mathrm{kPa}$.

(3) The usual clothing for miners was cotton trousers and long sleeved shirts. The thermal characteristics of these clothes have been previously measured and were entered into the air cooling power calculations.

Wet bulb globe temperature was approximated by the formula 0.7 psychrometric wet bulb temperature +0.3 dry bulb temperature. Dry bulb temperature was substituted for globe temperature in the standard equation. ${ }^{8}$ The wet bulb temperature was a psychrometric measure rather than a natural one as conventionally used in calculations of wet bulb globe temperature. For this reason we have referred to our measure as a psychrometric wet bulb globe temperature.

After recovery from heat illness, subjects were recalled on a rostered day off, or on a first day back before going underground, for measurement of their height, weight, and maximum $\mathrm{O}_{2}$ consumption $\left(\dot{\mathrm{V}}_{2} \mathrm{max}\right)$. The body mass index (BMI) was calculated as weight $/$ height $^{2}\left(\mathrm{~kg} / \mathrm{m}^{2}\right)$. The $\dot{\mathrm{V}}_{2} \max (\mathrm{ml} / \mathrm{kg} /$ min) was measured by submaximal exercise cycle testing with the Astrand protocol. Venous blood was tested for the same variables to detect any significant differences from the results obtained during heat exhaustion.

Incidences of heat exhaustion were calculated with the total number of underground miners as the denominator. Rates were calculated for the annual study period and for February, the month with the highest number of cases. Because heat and humidity increase with mine depth, the incidence of heat exhaustion was calculated for the three mines operating above $1200 \mathrm{~m}$ depth and for the two mines operating between 1200 and $1800 \mathrm{~m}$ depth. This was done to help determine the need for more ventilation and refrigeration in the deepest mines.

Work rates were classified as heavy or light according to the type of job being done at the onset of symptoms. For example, heavy work rates were assigned to ground support, rigging up drill rigs, timbering, shovelling, barring down, charging faces, and installing ventilation line. Light work rates were assigned to electrical work, diesel fitting, maintenance, surveying, mucking unit operation, welding, and truck driving.

To help clarify the role of dehydration and salt depletion in heat cramps, the serum sodium, urea, and creatinine concentrations were compared between miners with and without heat cramps.

To determine whether age, obesity, or poor cardiovascular fitness are risk factors for repeat episodes of heat exhaustion in this occupational setting, age, $\mathrm{BMI}$, and $\dot{\mathrm{V}}_{2}$ max data were compared between miners with and without repeat episodes of heat exhaustion. Air cooling power and work rate data were also compared, to see whether repeat episodes were due to hotter conditions or heavier work.

The study was approved by the Curtin University human research ethics committee.

\section{STATISTICAL ANALYSIS}

The two tailed, paired $t$ test was used to determine the significance of differences between the acute and recovery blood test results. $\chi^{2}$ Tests were used to find the significance of differences in observed and expected frequencies for cases occurring during the day shift and on the first shift. $\chi^{2}$ Tests were also used to find the significance of differences in the proportion of heavy versus light work undertaken by miners with and without repeated episodes of heat exhaustion. The two tailed, unpaired $t$ test was used to find the significance of differences in age, BMI, $\dot{\mathrm{V}}_{2} \max$ and air cooling power between groups with and without repeated episodes of heat exhaustion. The two tailed, unpaired $t$ test was also used to find the significance of differences in serum values between groups with and without cramps. The mean, $95 \%$ confidence interval for the mean $(95 \%$ CI), median, SD, and range were calculated for all variables. Cumulative percentage plots of occurrence of heat exhaustion relative to each of the underground thermal variables and relative to urinary specific gravity were generated. The $\chi^{2}$ tests were performed with EpiInfoStatcalc. All other statistical analyses were performed with Microsoft Excel.

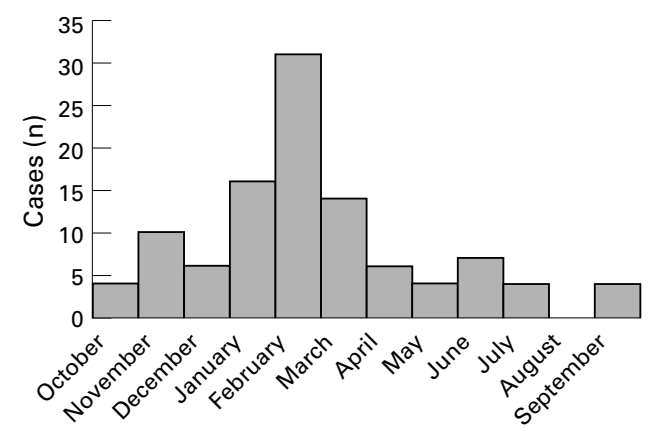

Figure 1 Number of heat exhaustion cases by month. 


\section{Results}

One hundred and six subjects were studied.

The mine's computer injury database recorded 118 cases in the same period. This indicates $90 \%$ of those cases satisfying the inclusion criteria were studied. The total number of underground miners during this period was 1252 . The incidence of heat exhaustion therefore was $94.2 / 1000 /$ year. This equates to 43.0 cases / million man-hours of underground work. Figure 1 shows the occurrence of cases by month of the year. In February the incidence reached 147 cases / million-man hours worked underground.

The incidence of heat exhaustion for the three mines operating above $1200 \mathrm{~m}$ depth was 18.4 / million-man hours. For the two mines operating between 1200 and $1800 \mathrm{~m}$ depth it was 58.3 / million man-hours. The rate ratio for heat exhaustion in the deeper mines was therefore 3.17 .

All subjects were men. Age, BMI, and $\dot{\mathrm{V}} \mathrm{O}_{2}$ max results are listed in table 1 . Eighty five cases $(80 \%)$ were doing heavy work as defined in the methods section.

Seventy six men had one episode, 10 men had two episodes, one man had four episodes, and one man had six episodes. The mean age, $\mathrm{BMI}$, and $\dot{\mathrm{V}}_{2} \mathrm{max}$ of miners with repeat episodes of heat exhaustion were not significantly different from miners who experienced only one episode (table 1). The proportion of heavy work being done by miners with repeat episodes of heat exhaustion (27 heavy / 30 total) was not significantly different from that done by miners who experienced only one episode (58 heavy / 76 total, $\mathrm{p}=0.186$ ). The air cooling power results were not significantly different for miners with (n 21, mean 146, 95\% CI 123 to 169, median 139, SD 53, range 79-255) and without (n 53, mean 149, 95\% CI 136 to 162 , median 148 , SD 48 , range 33-290) repeat episodes of heat exhaustion $(\mathrm{p}=0.826)$.

Table 1 Age, BMI and $\dot{V}_{2}$ max for all cases, for cases with a single episode of heat exhaustion and for cases with repeat episodes of heat exhaustion

\begin{tabular}{|c|c|c|c|c|c|c|c|}
\hline & $n$ & Mean & $95 \% C I$ & Median & $S D$ & Range & $p$ Value * \\
\hline \multicolumn{8}{|l|}{ All cases: } \\
\hline Age & 106 & 33.6 & 32.1 to 35.1 & 33.0 & 7.9 & $19-55$ & \\
\hline BMI & 96 & 29.6 & 28.7 to 30.5 & 29.6 & 4.4 & $20.2-40.6$ & \\
\hline$\dot{\mathrm{V}} \mathrm{O}_{2}$ max & 95 & 43.0 & 40.9 to 45.1 & 41.1 & 10.3 & $25.9-83.2$ & \\
\hline \multicolumn{8}{|c|}{ Single episode cases: } \\
\hline Age & 76 & 33.6 & 31.7 to 35.5 & 32.0 & 8.6 & $19-55$ & \\
\hline $\mathrm{BMI}$ & 66 & 29.1 & 28.1 to 30.2 & 28.6 & 4.5 & $20.2-40.6$ & \\
\hline$\dot{\mathrm{V}} \mathrm{O}_{2} \max$ & 65 & 43.2 & 40.5 to 45.9 & 40.7 & 11.2 & $25.9-83.2$ & \\
\hline \multicolumn{8}{|c|}{ Repeat cases: } \\
\hline Age & 12 & 34.6 & 31.6 to 37.5 & 34.5 & 5.2 & $24-46$ & 0.695 \\
\hline $\mathrm{BMI}$ & 12 & 30.4 & 27.9 to 32.9 & 30.7 & 4.5 & $20.8-36.0$ & 0.373 \\
\hline $\mathrm{V}_{2} \max$ & 12 & 40.0 & 36.0 to 44.0 & 40.7 & 7.1 & $27.5-49.4$ & 0.344 \\
\hline
\end{tabular}

$\star$ Single episode group $v$ repeat episode group.

Table 2 Underground thermal data

\begin{tabular}{llllll}
\hline & PWBT & DBT & AVEL & ACP & PWBGT \\
\hline n & 74 & 74 & 74 & 74 & 74 \\
Mean & 29.0 & 37.4 & 0.54 & 148 & 31.5 \\
95\% CI & 28.5 to 29.5 & 36.8 to 37.9 & 0.41 to 0.67 & 137 to 159 & 31.0 to 32.0 \\
Median & 29.8 & 38.0 & 0.42 & 144 & 31.7 \\
SD & 2.2 & 2.4 & 0.57 & 49 & 2.0 \\
Range & $21.0-34.0$ & $31.0-43.0$ & $0.00-4.00$ & $33-290$ & $25.2-35.3$ \\
95\% level* & 25.0 & 33.8 & 1.56 & 248 & 28.5 \\
\hline
\end{tabular}

${ }^{\star} 95 \%$ Of the cases occurred at less favourable thermal values than these. PWBT=psychometric wet bulb temperature; $\mathrm{DBT}=$ dry bulb temperature; $\mathrm{AVEL}=$ air velocity; $\mathrm{ACP}=$ air cooling power; PWBGT=psychometric wet bulb globe temperature.

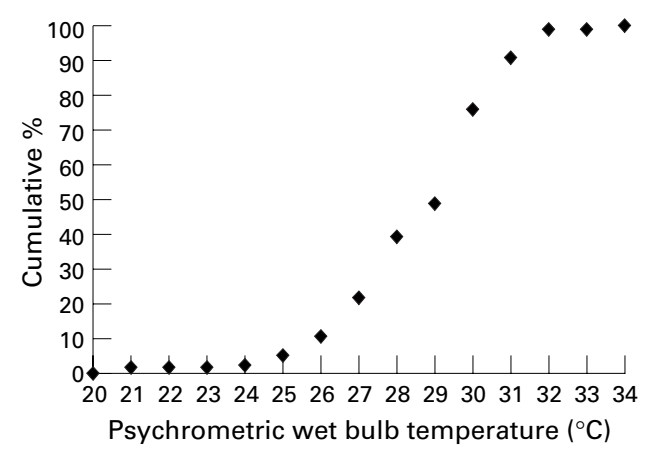

Figure 2 Cumulative percentage of heat exhaustion in relation to psychrometric wet bulb temperature $(n=74)$.

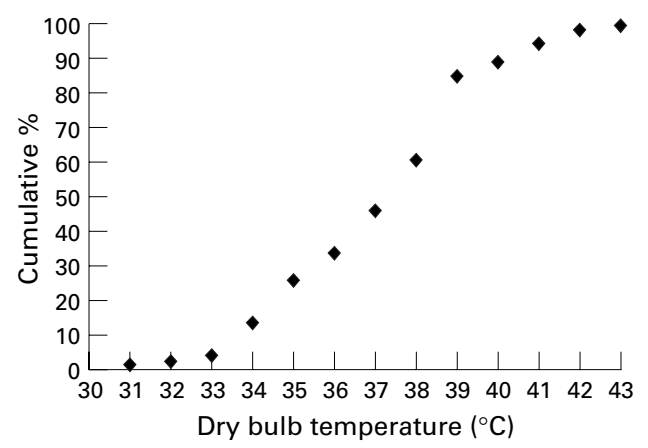

Figure 3 Cumulative percentage of heat exhaustion in relation to dry bulb temperature $(n=74)$.

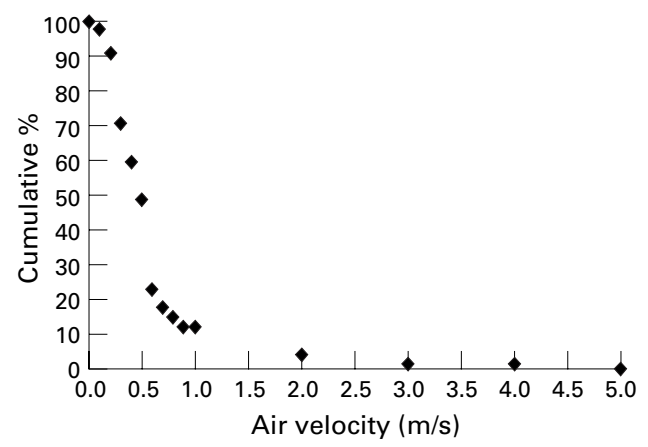

Figure 4 Cumulative percentage of heat exhaustion in relation to air velocity $(n=74)$

Sixty subjects $(57 \%)$ had been working at or near the face of a heading, where the ventilation was usually poor and the humidity high. Workplace thermal conditions were measured in 74 subjects $(70 \%)$. The results are listed in table 2 . The reasons for missing data included inability to contact the mine ventilation manager and loss of data by his field agents. Figures 2-6 are cumulative percentage graphs of occurrence of heat exhaustion relative to psychrometric wet bulb temperature, dry bulb temperature, air velocity, air cooling power, and psychrometric wet bulb globe temperature.

Seventy nine of the cases $(75 \%)$ occurred during the day shift whereas $50 \%$ would have been expected to occur during the day shift and $50 \%$ during the night shift $(\mathrm{p}<0.001)$. Forty four cases $(42 \%)$ occurred on the first day after rostered days off, whereas only $25 \%$ would have been expected to occur on the first day of a 4 day roster $(\mathrm{p}=0.01)$. 
Table 3 Haematology results

\begin{tabular}{|c|c|c|c|c|c|c|c|c|c|c|c|c|}
\hline & $\begin{array}{l}\text { Haemo- } \\
\text { globin }\end{array}$ & $\begin{array}{l}\text { Red cell } \\
\text { count }\end{array}$ & $\begin{array}{l}\text { Packed cell } \\
\text { volume }\end{array}$ & $\begin{array}{l}\text { Mean cell } \\
\text { volume }\end{array}$ & $\begin{array}{l}\text { Mean cell } \\
\text { haemoglobin }\end{array}$ & Platelets & $\begin{array}{l}\text { White cell } \\
\text { count }\end{array}$ & Neutrophils & $\begin{array}{l}\text { Lympho- } \\
\text { cytes }\end{array}$ & Monocytes & Eosinophils & Basophils \\
\hline Acute (n) & 106 & 105 & 105 & 105 & 105 & 102 & 106 & 105 & 105 & 105 & 105 & 105 \\
\hline Acute (mean) & 156 & 5.04 & 0.446 & 89.7 & 31.1 & 231 & 10.4 & 7.20 & 2.37 & 0.58 & 0.12 & 0.038 \\
\hline \multirow{2}{*}{$95 \% \mathrm{CI}$} & 154 to & 4.96 to & 0.439 to & 89.0 to & 30.8 to & 220 to & 9.8 to & 6.63 to & 2.21 to & 0.52 to & 0.10 to & 0.027 to \\
\hline & 159 & 5.13 & 0.453 & 90.3 & 31.4 & 241 & 11.0 & 7.78 & 2.54 & 0.65 & 0.15 & 0.049 \\
\hline Median & 156 & 5.00 & 0.440 & 90.0 & 31.0 & 227 & 9.7 & 6.80 & 2.30 & 0.50 & 0.10 & 0.000 \\
\hline SD & 12.4 & 0.44 & 0.036 & 3.2 & 1.3 & 54.3 & 3.3 & 3.02 & 0.88 & 0.33 & 0.13 & 0.057 \\
\hline Range & $122-189$ & $4.10-6.20$ & $0.350-0.550$ & $81.0-98.0$ & $27.0-35.0$ & $114-393$ & $4.5-21.6$ & $2.10-17.7$ & $0.30-5.40$ & $0.10-1.60$ & $0.00-0.53$ & $0.000-0.200$ \\
\hline Normal range & $135-180$ & $4.2-6.0$ & $0.38-0.52$ & $80-98$ & $27-35$ & $150-450$ & $4.0-11.0$ & $2.0-7.5$ & $1.1-4.0$ & $0.2-1.0$ & $0.04-0.4$ & $<0.21$ \\
\hline $\mathrm{n}>$ Normal range & 4 & 3 & 2 & 0 & 0 & 0 & 36 & 38 & 4 & 10 & 6 & 0 \\
\hline$\%>$ Normal range & 3.8 & 2.9 & 1.9 & 0 & 0 & 0 & 34 & 36.2 & 3.8 & 9.5 & 5.7 & 0 \\
\hline $\mathrm{n}<$ Normal range & 3 & 2 & 1 & 0 & 0 & 3 & 0 & 0 & 7 & 4 & 40 & \\
\hline$\%<$ Normal range & 2.8 & 1.9 & 0.95 & 0 & 0 & 2.9 & 0 & 0 & 6.7 & 3.8 & 38.1 & \\
\hline Recovery (n) & 86 & 86 & 86 & 86 & 86 & 81 & 86 & 86 & 86 & 86 & 86 & 86 \\
\hline Recovery (mean) & 152 & 4.92 & 0.434 & 89.5 & 31.1 & 217 & 7.4 & 4.42 & 2.28 & 0.44 & 0.21 & 0.026 \\
\hline \multirow[t]{2}{*}{$95 \% \mathrm{CI}$} & 150 to & 4.85 to & 0.428 to & 88.8 to & 30.8 to & 207 to & 7.0 to & 4.06 to & 2.13 to & 0.38 to & 0.17 to & 0.018 to \\
\hline & 154 & 4.99 & 0.439 & 90.2 & 31.4 & 226 & 7.8 & 4.78 & 2.43 & 0.50 & 0.25 & 0.034 \\
\hline $\mathrm{p}$ Value & 0.008 & 0.024 & 0.005 & 0.010 & 0.577 & 0.001 & $<0.001$ & $<0.001$ & 0.133 & $<0.001$ & 0.003 & 0.031 \\
\hline
\end{tabular}

Table 4 Biochemistry results

\begin{tabular}{|c|c|c|c|c|c|c|c|c|c|c|c|}
\hline & $\mathrm{Na}$ & $K$ & $C l$ & $\mathrm{HCO}_{3}$ & Anion gap & Lactate & Glucose & Urea & Creatinine & Osmolality & Ascorbate \\
\hline Acute (n) & 106 & 105 & 106 & 105 & 105 & 87 & 92 & 106 & 106 & 103 & 85 \\
\hline Acute (mean) & 141.2 & 4.20 & 100.3 & 25.6 & 19.5 & 2.06 & 6.20 & 6.84 & 0.132 & 299 & 33.4 \\
\hline \multirow[t]{2}{*}{$95 \% \mathrm{CI}$} & 140.5 to & 4.12 to & 99.5 to & 25.0 to & 18.6 to & 1.84 to & 5.90 to & 6.42 to & 0.122 to & 298 to & 26.9 to \\
\hline & 141.8 & 4.28 & 101.2 & 26.2 & 20.3 & 2.28 & 6.50 & 7.26 & 0.141 & 300 & 39.9 \\
\hline Median & 141.0 & 4.10 & 101.0 & 26.0 & 18.0 & 1.80 & 5.95 & 6.40 & 0.11 & 299 & 26.0 \\
\hline $\mathrm{SD}$ & 3.3 & 0.43 & 4.4 & 3.1 & 4.4 & 1.05 & 1.48 & 2.22 & 0.049 & 7.1 & 30.7 \\
\hline Range & $131.0-149.0$ & $3.10-5.50$ & $89.0-110.0$ & $16.0-33.0$ & $10.0-33.0$ & $0.90-8.40$ & $4.40-11.40$ & $3.30-14.90$ & $0.080-0.300$ & $270-318$ & $5.0-170$ \\
\hline Normal range & $137-147$ & $3.5-5.0$ & $96-109$ & $25-33$ & $4.0-17$ & $0.6-2.0$ & $3.0-7.7$ & $2.5-8.0$ & $0.06-0.13$ & $280-295$ & $10-115$ \\
\hline $\mathrm{n}>$ Normal range & 2 & 5 & 1 & 0 & 66 & 31 & 14 & 22 & 32 & 73 & 3 \\
\hline$\%>$ Normal range & 1.9 & 4.8 & 0.94 & 0 & 62.9 & 35.6 & 15.2 & 20.8 & 30.2 & 70.9 & 3.5 \\
\hline $\mathrm{n}<$ Normal range & 7 & 1 & 14 & 34 & 0 & 0 & 0 & 0 & 0 & 1 & 18 \\
\hline$\%<$ Normal range & 6.6 & 0.95 & 13.2 & 32.4 & 0 & 0 & 0 & 0 & 0 & 0.97 & 21.2 \\
\hline Recovery (n) & 88 & 88 & 88 & 88 & 88 & 47 & 78 & 88 & 87 & 87 & 80 \\
\hline Recovery (mean) & 140.7 & 4.13 & 102.1 & 26.9 & 15.9 & 2.07 & 5.47 & 5.01 & 0.093 & 297 & 34.5 \\
\hline \multirow[t]{2}{*}{$95 \% \mathrm{CI}$} & 140.2 to & 4.07 to & 101.6 to & 26.3 to & 15.3 to & 1.78 to & 5.20 to & 4.78 to & 0.090 to & 296 to & 28.2 to \\
\hline & 141.2 & 4.19 & 102.6 & 27.5 & 16.4 & 2.36 & 5.73 & 5.25 & 0.095 & 298 & 40.7 \\
\hline $\mathrm{p}$ Value & 0.259 & 0.160 & $<0.001$ & 0.011 & $<0.001$ & 0.425 & $<0.001$ & $<0.001$ & $<0.001$ & 0.030 & 0.409 \\
\hline
\end{tabular}

Mean estimated fluid intake was $0.64 \mathrm{l} / \mathrm{h}$ (95\% CI 0.58 to 0.69 , median 0.63 , SD 0.29 , range $0.08-1.50)$. Only 10 miners (9.4\%) drank $>1$ 1/h. Most miners were drinking plain water.

Only 10 miners (9.4\%) admitted alcohol consumption in the previous 24 hours.

Eight miners $(7.5 \%)$ had a current minor infective illness, being either gastroenteritis or upper respiratory tract infection.

Only one miner had been outside the tropics in the 2 weeks before presentation.

Symptom frequency was as follows: headache $71(67 \%)$, dizziness $60(57 \%)$, fatigue 83 $(78 \%)$, cramps $69(65 \%)$, nausea $86(81 \%)$, vomiting $50(47 \%)$, diarrhoea $10(9.4 \%)$, transient loss of consciousness $2(1.9 \%)$, confusion $1(0.9 \%)$. No convulsions occurred.

Mean tympanic temperature at presentation to the medical centre was $37.1^{\circ} \mathrm{C}(95 \%$ CI 37.0 to 37.2 , median 37.2 , SD 0.6 , range 36.0 38.4). Only five cases (4.7\%) exceeded 38.0.

Mean urine specific gravity on presentation to the medical centre before treatment was 1.027 (95\% CI 1.025 to 1.028 , median 1.028 , SD 0.006 , range 1.000-1.040). Nineteen miners $(18 \%)$ could not pass urine on presentation. Figure 7 shows the cumulative percentage of miners relative to urine specific gravity on presentation.

Mean pulse rate was $84 / \mathrm{min}(95 \%$ CI 82 to 86 , median 82, SD 12, range 50-126). Mean systolic blood pressure was $125 \mathrm{~mm} \mathrm{Hg}$ (95\% CI 122 to 128 , median 125, SD 14, range $90-160$ ). The heart rate exceeded $100 / \mathrm{min}$ in six subjects $(5.7 \%)$. The systolic blood pressure was $<100 \mathrm{~mm} \mathrm{Hg}$ in two subjects.

Table 3 lists the haematology results and tables 4 and 5 list the biochemistry results. Eighty nine $(84 \%)$ of the 106 acute cases participated in the recovery assessment. This was undertaken after a mean interval of 37 days (95\% CI 28 to 43 , median 23, SD 37, range 3-152).

Fifty patients $(47 \%)$ were treated with intravenous normal saline (1-4 1). This usually produced a rapid improvement in symptoms. Some patients preferred to avoid cannulation despite nausea limiting their tolerance for oral fluids. They usually took longer to recover than the patients given intravenous normal saline.

Four miners (3.8\%) were sent to hospital for further treatment. The rest were sent home after treatment. Seventy seven miners were due to work the next day. Of these, $47(61 \%)$ were asymptomatic and $30(39 \%)$ had persistent mild symptoms - such as headache and fatigue. Forty six (98\%) of the asymptomatic miners returned to normal duties and 22 $(73 \%)$ of the symptomatic miners were restricted to an air conditioned environment. None of these miners required further medical treatment. Of the 22 miners restricted to an air conditioned environment, 21 (95\%) returned to normal duties after one shift, and one required two shifts.

Sixty nine subjects (65\%) reported cramps and $37(35 \%)$ did not. Table 6 lists the serum sodium, urea, and creatinine results for these 
two groups. There was no significant difference between them for serum sodium $(p=0.384)$. However serum urea and creati-

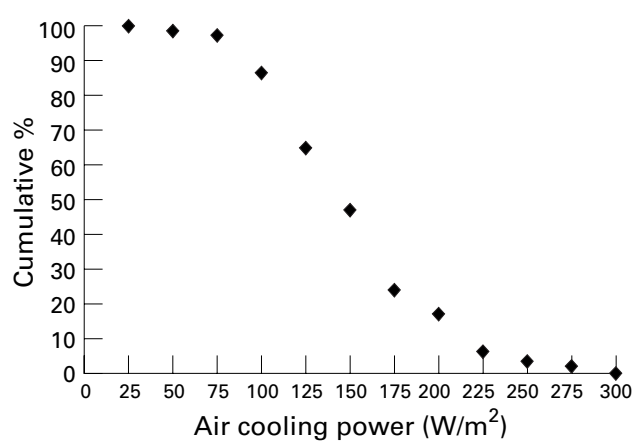

Figrue 5 Cumulative percentage of heat exhaustion in relation to air cooling power $(n=74)$.

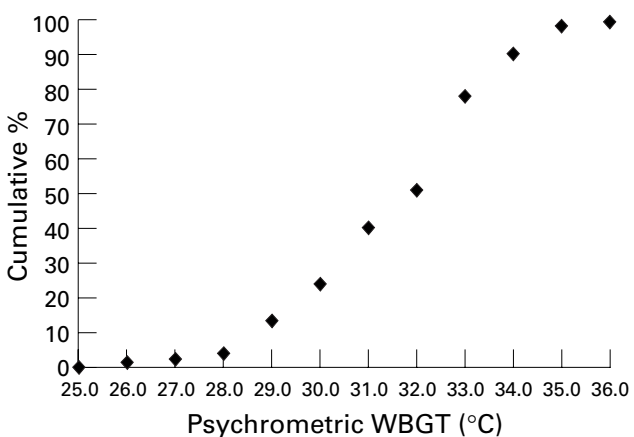

Figure 6 Cumulative percentage of heat exhaustion in relation to psychrometric wet bulb globe temperature $(n=74)$

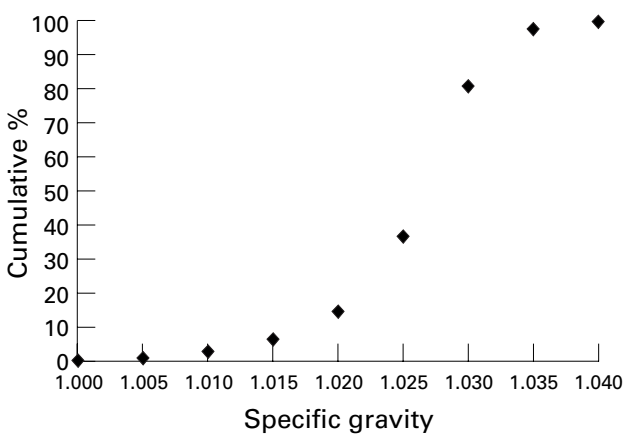

Figure 7 Cumulative percentage of heat exhaustion in relation to specific gravity of urine on presentation $(n=87)$. nine were significantly higher in the group with cramps.

\section{Discussion}

Heat exhaustion occurs relatively infrequently43.0 cases / million man-hours of underground work. However, the incidence is much higher during the summer months and in particular January to March. In February the incidence was 147 cases / million man-hours worked underground. Also the miners most often affected are those working in remote headings where the ventilation and refrigeration are at their worst. This subgroup of miners would have had a higher incidence of heat exhaustion.

The incidence rate ratio for heat exhaustion in the deeper mines was 3.17. This is consistent with the increasing heat exposure that occurs at depth due to the geothermal gradient and autocompression. It also highlights the need for improved ventilation and refrigeration at depth.

The results suggest that individual susceptibility exists but is uncommon. Seventy six subjects experienced a single episode of heat exhaustion. It is possible that the 10 men who experienced two episodes and the two men who experienced four and six episodes respectively do have susceptibility to heat exhaustion. The BMI, $\dot{\mathrm{V}}_{2} \max$, work rate, and air cooling power results were not significantly different in this group, when compared with the miners who experienced a single episode.

The median BMI of 29.6 was just within the World Health Organisation's overweight range of $25-30 .{ }^{19}$ This is a reflection of the heavy musculature and mild obesity present in many underground miners. The median $\mathrm{VO}_{2}$ max of $41.1 \mathrm{ml} / \mathrm{kg} / \mathrm{min}$ was just within the normal range for non-athletes aged 30-39, of 39-48 $\mathrm{ml} / \mathrm{kg} / \mathrm{min} .{ }^{20}$ It is possible that increased BMI and depressed $\dot{\mathrm{V}}_{2}$ max are risk factors for heat exhaustion in this occupational setting. Increased BMI has been found to be a significant risk factor for heat illness in soldiers undertaking paced work. ${ }^{21}{ }^{22}$ Poor aerobic fitness, as measured by $\dot{\mathrm{V}}_{2} \max$, has been significantly correlated with increased core temperatures during heat stress. ${ }^{23}{ }^{24}$ Poor aerobic fitness, as measured by prolonged run times in military

Table 5 Biochemistry results

\begin{tabular}{|c|c|c|c|c|c|c|c|c|c|c|c|}
\hline & $\begin{array}{l}\text { Alanine } \\
\text { transamin- } \\
\text { ase }\end{array}$ & $\begin{array}{l}\text { Creatine } \\
\text { kinase }\end{array}$ & $\begin{array}{l}\text { Creatine } \\
\text { kinase } \\
M B(\%)\end{array}$ & $\begin{array}{l}\text { Aspartate } \\
\text { transaminase }\end{array}$ & $\begin{array}{l}\text { Lactate } \\
\text { dehydro- } \\
\text { genase }\end{array}$ & $\begin{array}{l}\text { Activated } \\
\text { partial } \\
\text { thrombo- } \\
\text { plastin time }\end{array}$ & $\begin{array}{l}\text { Prothrombin } \\
\text { time }\end{array}$ & Iron & $\begin{array}{l}\text { Total iron } \\
\text { binding } \\
\text { capacity }\end{array}$ & $\begin{array}{l}\text { Transferrin } \\
\text { saturation }\end{array}$ & Ferritin \\
\hline Acute $(\mathrm{n})$ & 105 & 105 & 33 & 105 & 105 & 99 & 99 & 87 & 87 & 87 & 87 \\
\hline Acute (mean) & 33.2 & 227 & 3.69 & 31.9 & 189 & 29.4 & 14.8 & 15.6 & 69.2 & 23.1 & 281 \\
\hline \multirow[t]{2}{*}{$95 \% \mathrm{CI}$} & 29.7 to & 195 to & 3.31 to & 30.2 to & 181 to & 28.6 to & 14.6 to & 14.2 to & 66.5 to & 21.0 to & 247 to \\
\hline & 36.7 & 259 & 4.07 & 33.6 & 197 & 30.2 & 15.0 & 17.1 & 71.9 & 25.2 & 314 \\
\hline Median & 30.0 & 180 & 3.60 & 30.0 & 180 & 28.0 & 15.0 & 15.0 & 68.0 & 23.0 & 241 \\
\hline SD & 18.2 & 167 & 1.11 & 8.8 & 40 & 4.1 & 1.2 & 6.8 & 12.8 & 10.0 & 158 \\
\hline Range & $12.0-101$ & $38-1100$ & $1.40-6.00$ & $19.0-79.0$ & $126-364$ & $25.0-38.0$ & $12.0-17.0$ & $3.0-52.0$ & $45.0-100$ & $6.0-65.0$ & $41-804$ \\
\hline Normal range & $0-45$ & $0-190$ & $<4.0$ & $0-41$ & $80-250$ & $25-38$ & $12.0-17.0$ & $10.0-33$ & $45-70$ & $16-50$ & $20-320$ \\
\hline $\mathrm{n}>$ Normal range & 20 & 47 & 12 & 15 & 10 & 0 & 0 & 1 & 33 & 1 & 23 \\
\hline$\%>$ Normal range & 19 & 44.8 & 36.4 & 14.3 & 9.5 & 0 & 0 & 1.1 & 37.9 & 1.1 & 26.4 \\
\hline $\mathrm{n}<$ Normal range & & & & & 0 & 0 & 0 & 12 & 0 & 20 & 0 \\
\hline$\%<$ Normal range & & & & & 0 & 0 & 0 & 13.8 & 0 & 23 & 0 \\
\hline Recovery (n) & 88 & 88 & & 88 & 88 & 83 & 83 & 83 & 82 & 82 & 82 \\
\hline Recovery (mean) & 33.0 & 174 & & 27.5 & 165 & 31.1 & 14.7 & 15.7 & 63.3 & 25.0 & 243 \\
\hline \multirow[t]{2}{*}{$95 \% \mathrm{CI}$} & 28.8 to & 137 to & & 25.5 to & 160 to & 30.0 to & 14.3 to & 14.6 to & 61.3 to & 23.2 to & 210 to \\
\hline & 37.2 & 211 & & 29.6 & 170 & 32.3 & 15.1 & 16.8 & 65.3 & 26.8 & 276 \\
\hline $\mathrm{p}$ Value & 0.683 & 0.002 & & $<0.001$ & $<0.001$ & 0.026 & 0.456 & 0.868 & $<0.001$ & 0.120 & $<0.001$ \\
\hline
\end{tabular}


Table 6 Serum sodium, urea, and creatinine in cases with and without heat cramps

\begin{tabular}{|c|c|c|c|c|c|c|c|}
\hline & $n$ & Mean & $95 \% C I$ & Median & $S D$ & Range & $p$ Value \\
\hline \multicolumn{8}{|l|}{ Heat cramps: } \\
\hline Sodium & 69 & 141.0 & 140.2 to 141.8 & 141.0 & 3.4 & $131.0-149.0$ & \\
\hline Urea & 69 & 7.37 & 6.81 to 7.93 & 7.10 & 2.38 & $3.30-14.9$ & \\
\hline Creatinine & 69 & 0.144 & 0.132 to 0.157 & 0.120 & 0.054 & $0.080-0.30$ & \\
\hline \multicolumn{8}{|c|}{ No heat cramps: } \\
\hline Sodium & 37 & 141.5 & 140.5 to 142.5 & 141.0 & 3.1 & $135.0-149.0$ & 0.384 \\
\hline Urea & 37 & 5.85 & 5.39 to 6.31 & 5.60 & 1.42 & $3.70-10.6$ & $<0.001$ \\
\hline Creatinine & 37 & 0.108 & 0.100 to 0.117 & 0.100 & 0.027 & $0.080-0.230$ & $<0.001$ \\
\hline
\end{tabular}

fitness tests, has also been found to be a significant risk factor for heat illness. ${ }^{21}$

Significantly more cases occurred on the first shift, and during the day shift, than would have been expected. The most common roster was two 12 hour day shifts, two 12 hour night shifts, then 4 days off. Diurnal variation in the thermal environment underground is minimal. The predominance of cases on the first shift, which is a day shift, probably resulted in the predominance of cases occurring during the day. Loss of acclimatisation is unlikely to explain the excess of cases occurring on the first day shift. This is because only one miner left the tropics within the 2 weeks preceding heat exhaustion, and the 4 day break between shifts is not long enough to lose acclimatisation. It is more likely that outdoor recreational activities and alcohol consumption have resulted in dehydration before starting the first shift.

Fluid intake was clearly inadequate. The raised serum osmolality, urea, creatinine, and urine specific gravity (fig 2) indicate marked dehydration. Estimated fluid intake was much less than the maximum gastrointestinal absorption rate of $1.4-1.8 \mathrm{1} / \mathrm{h} .{ }^{25}{ }^{26}$ Urine specific gravity may be of use in educating underground miners as to the fluid intake required to prevent dehydration. A urine specific gravity of $<1.015$ on going underground and of $<1.025$ on surfacing might be expected to reduce the incidence of heat exhaustion. Alternatively, comparison of urine colour with photographs of urine samples known to be of these specific gravities would avoid the need for specific gravity testing and may be more practical for many miners. Urine colour has been shown to correlate well with specific gravity and dehydration measured by changes in body mass. ${ }^{27}$

Febrile illness, use of medication, recent travel outside of the tropics, and alcohol consumption during the previous 24 hours were uncommon risk factors. It is possible that alcohol was consumed more often than was admitted to, as there is a workplace alcohol testing policy with random, accident, and high potential incident tests.

Core temperature on presentation was only mildly increased and never exceeded $38.5^{\circ} \mathrm{C}$. Core temperatures have been found to fall considerably during transport from the field to a medical centre. ${ }^{11}$ It is certainly possible that this occurred in our study, retrieval by four wheel drive ambulance typically taking 20-30 minutes from receipt of the call out. This possibility makes it impossible to exclude hyperthermia as a contributor to the findings. The fact that nine subjects $(8.5 \%)$ had a urine specific gravity $<1.020$ suggests there may be a direct hyperthermic effect.

The haemoglobin, red cell count, packed cell volume, and platelet concentrations were significantly increased on presentation compared with recovery, suggesting haemoconcentration due to dehydration. There was no evidence of the platelet consumption reported in heat stroke. ${ }^{28-34}$

The white cell count was significantly increased, mainly due to a rise in neutrophils. Thirty eight miners (36\%) had frank neutrophil leukocytosis. This suggests a considerable stress response. ${ }^{35}$ The monocyte concentration was significantly increased which may reflect increased cytokine production in response to heat. The eosinophil concentration was significantly decreased. Forty miners (38\%) had frank eosinopenia. This suggests a considerable stress response. ${ }^{35}$ We are not aware of any previous reports of neutrophil leukocytosis or eosinopenia in heat exhaustion. Both of these features, however, have been reported in subjects exercised to volitional exhaustion. ${ }^{36}$

The sodium and potassium concentrations were not significantly different on presentation compared with recovery. Sweat is hypotonic so water would have been lost out of proportion to sodium. Volume depletion would have induced renal sodium retention by way of the reninangiotensin-aldosterone system. Increased concentrations of plasma renin and aldosterone have been found in dehydrated subjects exercising in heat. ${ }^{37}$ For these reasons it is not surprising that hyponatraemia did not occur. As the recovery sodium concentrations were normal despite continued work in hot conditions, it seems that dietary intake of sodium is adequate to replace losses in sweat without adding sodium to the water consumed at work. Of course, if an adequate fluid intake was maintained so as to prevent dehydration and sodium chloride was added at a concentration similar to that in sweat, there would probably be less disturbance of the renin-angiotensinaldosterone system. The long term effects of repeated activation of the renin-angiotensinaldosterone system by dehydration due to work in hot conditions are unknown.

The chloride and bicarbonate concentrations were significantly decreased. Fourteen subjects $(13 \%)$ and 34 subjects $(32 \%)$, respectively, were below the normal range. The anion gap was significantly increased. Sixty six subjects $(63 \%)$ exceeded the normal range. These results suggest that metabolic acidosis occurred causing an increased anion gap, depressed bicarbonate, and renal exchange of chloride in favour of bicarbonate. ${ }^{38}{ }^{39}$ Although lactate was not significantly increased on presentation compared with recovery, 31 miners (36\%) exceeded the normal range. It is likely that lactate contributed to the metabolic acidosis.

The glucose concentration was significantly increased and 14 miners (15\%) exceeded the normal range for random glucose. Nine of these had a glucose tolerance test and two satisfied the criteria for diabetes mellitus. Given that most of these subjects had not eaten 
recently and that they were engaged in manual labour it is somewhat surprising to find the glucose concentration increased. Perhaps it is in response to catecholamine secretion, known to occur during exercise in heat. ${ }^{37} 40$

Urea and creatinine were significantly increased. Twenty two (21\%) and $32(30 \%)$ subjects, respectively, exceeded the normal range. This reflects marked dehydration. The return to normal on recovery precluded chronic renal failure as a cause for these findings.

Serum osmolality was significantly increased and 73 subjects $(71 \%)$ exceeded the normal range. This reflects dehydration. As the sodium concentrations were normal, it is likely that the increased urea and glucose contributed to the increased osmolality. Recovery serum osmolality was also increased compared with normal. A rise in serum osmolality has been reported in subjects undergoing acclimatisation. ${ }^{41}$ However, it is also likely that dehydration occurs in miners on days off as a result of recreational activities in the heat.

Ascorbate was not significantly different on presentation than on recovery. However 18 subjects $(21 \%)$ were below the normal range on presentation. Ascorbate deficiency has been associated with impaired heat tolerance and acclimatisation, ${ }^{42}$ and it would seem that it may also be associated with an increased risk of heat exhaustion.

Creatine kinase, aspartate transaminase, and lactate dehydrogenase were significantly increased. Alanine transaminase was not significantly different on presentation and on recovery. However, 20 subjects $(19 \%)$ exceeded the normal range on presentation. The magnitude of the rise in all of these enzymes was much smaller than that found in heatstroke..$^{4-6} 10$ However, peak aspartate transaminase, alanine transaminase, and lactate dehydrogenase concentrations in heat stroke have been found at $48-72$ hours. ${ }^{56}$ It is possible therefore, that these enzymes may have reached higher concentrations after presentation.

There was no evidence of the coagulation abnormalities reported in heat stroke. ${ }^{28-34}$

Serum ferritin and total iron binding capacity were significantly increased. Twenty three subjects $(26 \%)$ and 33 subjects (38\%), respectively, exceeded the normal range. Although ferritin was increased there was no increase of serum iron, suggesting an acute phase reaction, rather than haemochromatosis. Increased transferrin has been reported in subjects exercised to volitional exhaustion. ${ }^{36}$

Serum urea and creatinine were significantly higher in those miners who experienced cramps than in those who did not (table 6). Serum sodium, however, was not significantly different. This suggests that dehydration rather than low serum sodium concentration is the cause of heat cramps. The frequent presence of heat cramps in cases of heat exhaustion (65\%), suggests that the traditional distinction between the two conditions is unhelpful. It may be more appropriate to regard heat cramps as one of the symptoms that may occur in heat exhaustion.
Unfortunately thermal data from underground areas where heat exhaustion did not occur were not recorded, so it is not possible to measure the risk of heat exhaustion for given levels of psychrometric wet bulb temperature, dry bulb temperature, air velocity, air cooling power, or psychrometric wet bulb globe temperature. However, it is clear that few cases of heat exhaustion $(<5 \%)$ occurred at psychrometric wet bulb temperature $<25.0^{\circ} \mathrm{C}$, dry bulb temperature $<33.8^{\circ} \mathrm{C}$, air velocity $>1.56$ $\mathrm{m} / \mathrm{s}$, air cooling power $>248 \mathrm{~W} / \mathrm{m}^{2}$, or psychrometric wet bulb globe temperature $<28.5^{\circ} \mathrm{C}$. It seems likely, therefore, that heat exhaustion would be practically eliminated if ventilation and refrigeration systems achieved air cooling power $>250 \mathrm{~W} / \mathrm{m}^{2}$ at all underground work sites.

At a wet bulb globe temperature of $28.5^{\circ} \mathrm{C}$ the American Conference of Governmental Industrial Hygienists threshold limit value (ACGIH TLV) system would prescribe a maximum work rest cycle of $25 \%$ work / $75 \%$ rest for heavy work, $50 \%$ work / $50 \%$ rest for moderate work, or continuous light work. ${ }^{8}$ Our finding that $5 \%$ of subjects of heat exhaustion occurred at a psychrometric wet bulb globe temperature of $28.5^{\circ} \mathrm{C}$ is in reasonable agreement with the ACGIH work rest prescription given that it is likely that underground miners generally exceed these levels of activity, and psychrometric wet bulb globe temperature underestimates wet bulb globe temperature.

It also seems that there is reasonable agreement between air cooling power and wet bulb globe temperature. An air cooling power of $248 \mathrm{~W} / \mathrm{m}^{2}$ implies that a continuous moderate work load can be sustained without net heat gain. ${ }^{1}$

Previous studies of South African gold miners found that cases of heat stroke began to occur above wet bulb temperatures of $26.5-28.3^{\circ} \mathrm{C}^{3}{ }^{6712}$ Given that heat exhaustion is a less severe end point than heat stroke, these slightly higher wet bulb temperatures are consistent with our findings.

A case series of heat cramps, heat exhaustion, and heat collapse in South African gold miners reported a mean wet bulb temperature of $31.6^{\circ} \mathrm{C}$ (95\% CI 31.0 to 32.2$) .{ }^{13}$ This is somewhat higher than the mean psychrometric wet bulb temperature of $29.0^{\circ} \mathrm{C}(95 \%$ CI 28.5 to 29.5 ) found in our series. Unfortunately the South African series did not report the lower limit or percentiles of the wet bulb temperature, so it is difficult to compare the value at which heat exhaustion began to occur. Air velocity, air cooling power, and wet bulb globe temperature were not reported.

Mine productivity (tonnes/month) has been reported to fall at air cooling powers $<300$ $\mathrm{W} / \mathrm{m}^{2}{ }^{18}$ Declining productivity therefore occurs at air cooling powers above those associated with heat exhaustion. This is not surprising, as physiologically it would be expected fatigue would occur before heat exhaustion.

To prevent heat exhaustion and poor productivity the aim should be to provide air cooling powers $>250 \mathrm{~W} / \mathrm{m}^{2}$. The best way to do this is by refrigeration and ventilation; however, 
refrigeration costs can be very high. It is also important to minimise heat production with energy efficient machinery and control of groundwater and mine water. ${ }^{2}$ Portable air movers are cheap and can improve air cooling power considerably in remote headings by increasing air velocity. However, they require frequent relocation and will not put right other issues related to ventilation-such as the removal of air contaminants and supply of fresh air.

Although we have been able to define a threshold of thermal conditions for underground mining beyond which heat exhaustion can be expected, more research is required to define the risk of heat exhaustion beyond this threshold. The descriptive data presented in figures $2-6$ suggest the sort of relation that may be found. Having defined the risk of heat exhaustion at given thermal levels, it will be necessary for all stakeholders in mining to agree on what is an acceptable risk and set a withdrawal limit. To minimise the risk of heat exhaustion at a given thermal level, it is important to ensure:

- Education to promote hydration before, during, and after work

- Education to promote self pacing (slowing the work rate or resting more often in worse conditions)

- Early reporting of symptoms and ending work when they occur.

Because underground miners often work alone, are usually supervised intermittently, and often vary their tasks and work rate, the use of formal work rest cycles is not really practicable.

Hand held electronic instruments that measure wet bulb temperature, dry bulb temperature, globe temperature, air velocity, and calculate wet bulb globe temperature and air cooling power should soon be commercially available. ${ }^{43}$ It is hoped that these will facilitate recognition of ventilation and refrigeration deficiencies, as well as recognition of thermal conditions that require withdrawal. Prototypes are currently being used at this mine.

Heat stroke does not occur at this mine despite work being undertaken at times in conditions previously associated with a high risk of heat stroke in South African mines (wet bulb temperature $\left.>32.5^{\circ} \mathrm{C}\right) .^{312}$ We suggest two reasons for this. Firstly, the work rate of miners in South Africa in the past was paced whereas work in this Australian mine is self paced. ${ }^{12}$ When faced with extreme conditions, miners here are able to reduce their work rate, and rest, thereby reducing the required heat loss. Secondly, miners with symptoms of heat exhaustion here are able to stop work. This may not have been the case in South Africa in the past, and it is likely that continued paced work in miners with heat exhaustion would result in heat stroke. Lind suggested similar reasons for the absence of heat stroke in European coal miners. ${ }^{44}$ The risk that paced work represents in extreme thermal conditions is clear. Contract mining today commonly involves financial incentives to maximise development and rates of production. Miners may be tempted by these incentives to maintain inappropriately high work rates and ignore symptoms of heat exhaustion. Controls must be in place to prevent this.

In summary-heat exhaustion in underground miners is an important acute occupational disease associated with dehydration (increased urea, creatinine, osmolality), neutrophil leukocytosis, eosinopenia, metabolic acidosis (increased anion gap, depressed bicarbonate) increased glucose and ferritin, and a mild rise in creatin kinase, aspartate transaminase, and lactate dehydrogenase. The incidence increased considerably during the summer and at depth. Heat exhaustion is unlikely to occur if an air cooling power $>250 \mathrm{~W} / \mathrm{m}^{2}$ is achieved at all underground sites. Education to promote hydration, self pacing, and the early reporting of symptoms is required. Hierarchy of control considerations, however, indicate the need to improve thermal conditions where practicable and prevent work in those conditions that present an unacceptable risk of heat exhaustion. More research is needed to define the risk of heat exhaustion beyond the thermal threshold. Then stakeholders need to reach a consensus on what is an unacceptable risk and define a withdrawal limit.

We thank Mr Rick Brake, mine ventilation manager, for his valued assistance and support over the duration of the study.

1 Pickering EIAJ, Tuck MA. Heat: sources, evaluation, determination of heat stress and heat stress treatment. Mining Technology 1997;79:147-56.

2 Hartman HL, Mutmansky JM, Ramani RV, et al. Mine ventilation and air conditioning. New York: John Wiley, 1997.

3 Kew MC. Temperature regulation in heatstroke in man. Isr f Med Sci 1976;12:759-64

4 Kew MC, Bersohn I, Peter J, et al. Preliminary observations on the serum and cerebrospinal fluid enzymes in heatstroke. S Afr Med f 1967;41:530-2.

5 Kew M, Bersohn I, Seftel H. The diagnostic and prognostic significance of the serum enzyme changes in heatstroke. Trans R Soc Trop Med Hyg 1971;65:325-30.

6 Kew M, Bersohn I, Seftel H, et al. Liver damage in heatstroke. Am f Med 1970;49:192-202. $7 \mathrm{Kew} \mathrm{MC,} \mathrm{Abrahams} \mathrm{C,} \mathrm{Levin} \mathrm{NW,} \mathrm{et} \mathrm{al.} \mathrm{The} \mathrm{effects} \mathrm{of}$ Med 1967;36:277-300.

8 Schutte PC, Zenz C. Physical work and heat stress. In: Zenz C, Dickerson OB, Horvath EP. Occupational medicine, 3rd edition. St Louis: Mosby, 1994:321.

9 Dickinson JG. History and epidemiology: definitions and groups at risk. In: Hopkins PM, Ellis FR, eds. Hyperthermic and hypermetabolic disorders: exertional heat stroke, malignant hyperthermia and related syndromes. Cambridge: Cambridge University Press; 1996:3-19.

10 Shibolet S, Coll R, Gilat T, et al. Heatstroke: its clinical picture and mechanism in 36 cases. Qf Med 1967;36:525-48.

11 Shapiro Y, Seidman DS. Field and clinical observations of exertional heat stroke patients. Med Sci Sports Exerc 1990;22:6-14

12 Wyndham $\mathrm{CH}$, Allan AMcD, Bredell GAG, et al. Assessing the heat stress and establishing the limits for work in a hot mine. Br f Ind Med 1967;24:255-71.

13 Shearer S. Dehydration and serum electrolyte changes in South African gold miners with heat disorders. Am $₹$ Ind Med 1990;17:225-39.

14 Mitchell D, Whillier A. Cooling power of underground environments. Fournal of the South African Institute of Mininvironments. Fournal of the South

15 Stewart JM, Van Rensburg AJ. Heat stress limits for men working in the gold mining industry. Fournal of the Mine Ventilation Society of South Africa 1977;30:85-95.

$16 \mathrm{McPherson}$ MJ. The generalization of air cooling power. Proceedings of the 5th International Mine Ventilation Congress. Johannesburg, South Africa: Mine Ventilation Society of South Africa, 1992.

17 Withdrawn.

18 Howes MJ, Nixon CA. Development of procedures for safe working in hot conditions. Proceedings of the 6th International Mine Ventilation Congress. Society for Mining, Metallurgy, and Exploration, 1997.

19 World Health Organisation Expert Committee on Physical Status. The use and interpretation of anthropometry 1995. Ptatus. The use and interpretation of anthropometry 1995. Physical status: the use and interpretation of anthropometry:
report of a WHO expert committee. Geneva: WHO, 1995. report of a WHO expert committee.
(WHO technical report series 854 .) 
20 Wilmore JH, Costill DL. Physiology of sport and exercise. Champaign: Human Kinetics; 1994

21 Gardner JW, Kark JA, Karnei K, et al. Risk factors predicting exertional heat illness in male Marine Corps recruits. Med Sci Sports Exerc 1996;28:939-44.

22 Chung NK Obesity and the occurrence of heat disorders Mil Med 1996;161:739-42.

23 Havenith G, van Middendorp H. The relative influence of physical fitness, acclimatization state, anthropometric measures and gender on individual reactions to heat stress. Eur 7 Appl Physiol 1990;61:419-27.

24 Sawka MN, Wenger CB, Pandolf KB. Thermoregulatory responses to acute exercise-heat stress and heat acclimation. In: Fregly MJ, Blatteis CM, eds. Handbook of physiology. Section 4 . Volume 1. Environmental physiology. New York: Oxford University Press; 1996:157-85.

25 Gisolfi CV, Duchman SM. Guidelines for optimal replacement beverages for different athletic events. Med Sci Sports Exer 1992;24:679-87.

26 Gisolfi C. Gastrointestinal function during exercise. In: Sutton JR, Thompson MW, Torade ME, eds. Proceedings of the 10th Biennial Conference on Exercise and Therm

27 Armstrong LE, Herrera Soto JA, Hacker FT, et al. Urinary indicies during dehydration, exercise, and rehydration. Int $\mathcal{F}$ Sport Nutr 1998;8:345-55.

28 Sohal RS, Sun SC, Colcolough HL, et al. Heat stroke. An electron microscopic study of endothelial cell damage and disseminated intravascular coagulation. Arch Intern Med 1968;122:43-7

29 Meikle AW, Graybill JR. Fibrinolysis and haemorrhage in a fatal case of heat stroke. $N$ Engl 7 Med 1967;276:911-13.

30 O'Donnell TF. Acute heat stroke. Epidemiologic, biochemical, renal, and coagulation studies. $7 A M A$ 1975;234:824-8.

1 Gader AMA, Al-Mashhadani SA, Al-Harthy SS. Direct activation of platelets by heat is the possible trigger of the activation of platelets by he 7 Hacmatol 1990;74:86-92

Beard MEJ, Hickton CM. Haemostasis in heat stroke. $\mathrm{Br} F$ Haematol 1982;52:269-74.
33 Mustafa KY, Omer O, Khogali M, et al. Blood coagulation and fibrinolysis in heat stroke. Br f Haematol 1985;61:51723.

34 Weber MB, Blakely JA. The haemorrhagic diathesis of heatstroke. A consumption coagulopathy successfully treated with heparin. Lancet 1969;7607:1190-2.

35 Dale DC. Leukocytosis, leukopenia and eosinophilia. In: Wilson JD, Braunwald E, Isselbacher KJ, et al, eds. Harrison's principles of internal medicine, 12th ed. New York: McGraw Hill; 1991:359-62.

36 Fry RW, Morton AR, Garcia-Webb P, et al. Acute interval training and haematology. Excel 1992;8:25-30.

37 Melin B, Jimenez C, Savourey G, et al. Effects of hydration state on hormonal and renal responses during moderate exercise in the heat. Eur f Appl Physiol 1997;76:320-7.

38 Levinsky N. Acidosis and alkalosis. In: Wilson JD, Braunwald E, Isselbacher $\mathrm{KJ}$, et al eds. Harrison's principles of internal medicine, 12th ed. New York: McGraw Hill, 1991: of internal

39 Ganong WF. Review of medical physiology, 16th ed. East Norwalk: Appleton and Lange, 1993: 656-8.

40 Hoffman JR, Maresh CM, Armstrong LE, et al. Effects of hydration state on plasma testosterone, cortisol and catecholamine concentrations before and during mild exercise at elevated temperature. Eur F Appl Physiol 1994;69: 294-300.

41 Mudambo KSMT, Coutie W, Rennie MJ. Plasma arginine vasopressin, atrial natriuretic peptide and brain natriuretic peptide responses to long term field training in the heat: effects of fluid ingestion and acclimatization. Eur $\mathcal{F} A p p l$ Physiol 1997;75:219-25.

42 Strydom NB, Kotze HF, Van Der Welt WH, et al. Effect of ascorbic acid on rate of heat acclimatization. $\mathcal{F}$ Appl Physiol 1976;41:202-5.

43 http://www.swri.org/!offline/techtday/heat.htm

44 Lind AR. The lack of heatstroke in European miners working in hot climates. Am Ind Hyg Assoc 7 1970;31:460-5.

\section{Vancouver style}

All manuscripts submitted to Occup Environ Med should conform to the uniform requirements for manuscripts submitted to biomedical journals (known as the Vancouver style.)

Occup Environ Med, together with many other international biomedical journals, has agreed to accept articles prepared in accordance with the Vancouver style. The style (described in full in the $\mathcal{F} A M A[1]$ ) is intended to standardise requirements for authors, and is the same as in this issue.

References should be numbered consecutively in the order in which they are first mentioned in the text by Arabic numerals on the line in square brackets on each occasion the reference is cited (Manson[1] confirmed other reports[2][3][4][5]). In future references to papers submitted to Occup Environ Med should include: the names of all authors if there are three or less or, if there are more, the first three followed by et al; the title of journal articles or book chapters; the titles of journals abbreviated according to the style of Index Medicus; and the first and final page numbers of the article or chapter. Titles not in Index Medicus should be given in full.

Examples of common forms of references are:

1 International Committee of Medical Journal Editors. Uniform requirements for manuscripts submitted to Uniform requirements for manuscripts
biomed journals. $¥ A M A$ 1993;269:2282-6.

2 Soter NA, Wasserman SI, Austen KF. Cold urticaria: release into the circulation of histmaine and eosinophil chemotactic factor of anaphylaxis during cold challenge. Engl f Med 1976;294:687-90.

3 Weinstein L, Swartz MN. Pathogenic properties of invading micro-organisms. In: Sodeman WA Jr, Sodeman WA, eds. Pathologic physiology, mechanisms of disease. Philadelphia: W B Saunders, 1974:457-72. 